\title{
Maximizing biofuel production in a thermochemical biorefinery by adding electrolytic hydrogen and by integrating torrefaction with entrained flow gasification
}

\section{Clausen, Lasse Røngaard}

\section{Published in:}

Energy

Link to article, DOI:

10.1016/j.energy.2015.03.089

Publication date:

2015

Document Version

Peer reviewed version

Link back to DTU Orbit

Citation (APA):

Clausen, L. R. (2015). Maximizing biofuel production in a thermochemical biorefinery by adding electrolytic hydrogen and by integrating torrefaction with entrained flow gasification. Energy, 85, 94-101.

https://doi.org/10.1016/j.energy.2015.03.089

\section{General rights}

Copyright and moral rights for the publications made accessible in the public portal are retained by the authors and/or other copyright owners and it is a condition of accessing publications that users recognise and abide by the legal requirements associated with these rights.

- Users may download and print one copy of any publication from the public portal for the purpose of private study or research.

- You may not further distribute the material or use it for any profit-making activity or commercial gain

- You may freely distribute the URL identifying the publication in the public portal 


\title{
Maximizing biofuel production in a thermochemical biorefinery by adding electrolytic hydrogen and by integrating torrefaction with entrained flow gasification
}

\author{
Lasse R. Clausen* \\ Section of Thermal Energy, Department of Mechanical Engineering, The Technical University of Denmark (DTU), \\ Nils Koppels Allé Bld. 403, DK-2800 Kgs. Lyngby, Denmark
}

Received: $\mathbf{x x}$

\begin{abstract}
In a "conventional" thermochemical biorefinery, carbon is emitted from the plant in the form of $\mathrm{CO}_{2}$ to make the synthesis gas from the gasifier suitable for fuel production. The alternative to this carbon removal is to add hydrogen to the plant. By adding hydrogen, it is possible to more than double the biofuel production per biomass input by converting almost all of the carbon in the biomass feed to carbon stored in the biofuel product. Water or steam electrolysis can supply the hydrogen to the biorefinery and also the oxygen for the gasifier. This paper presents the design and thermodynamic analysis of two biorefineries integrating water electrolysis for the production of methanol. In both plants, torrefied woody biomass is supplied to an entrained flow gasifier, but in one of the plants, the torrefaction process occurs on-site, as it is integrated with the entrained flow gasification process. The analysis shows that the biorefinery with integrated torrefaction has a higher biomass to methanol energy ratio ( $136 \%$ vs. $101 \%$ ) as well as higher total energy efficiency (62\% vs. $56 \%)$. By comparing with two identical biorefineries without electrolysis, it is concluded that the biorefinery with integrated torrefaction benefits most from the integration of electrolysis.
\end{abstract}

Keywords: biorefinery, biofuel, electrolysis, torrefaction, gasification, thermodynamic analysis.

\section{Introduction}

A thermochemical biorefinery can be based on gasification of a biomass feedstock to produce a synthesis gas (syngas) followed by chemical synthesis in a chemical reactor to produce the desired biofuel. Thermochemical biorefineries of this type are currently being demonstrated and upscaled all over the world [1]. An example of an existing demonstration plant is the $32 \mathrm{MWth}$ GoBiGas plant in Sweden, producing synthetic natural gas [1]. The carbon-based biofuels produced by a thermochemical biorefinery will have hydrogen to carbon ratios that are higher than those of biomass feedstocks. This means that there is a need to adjust the hydrogen to carbon ratio in the bio-syngas before the chemical synthesis. The conventional way of doing this adjustment is by changing the $\mathrm{H}_{2} / \mathrm{CO}$-ratio in the syngas by using the water gas shift (WGS) reaction (eq. 1) followed by removal of the produced $\mathrm{CO}_{2}$ [2]. This $\mathrm{CO}_{2}$ will typically be vented to the atmosphere, but if it was compressed and stored underground (CCS), the complete biorefinery would have the effect of reducing the $\mathrm{CO}_{2}$ content in the atmosphere and would thereby be a climate-mitigating technology. Such a biorefinery is investigated in, e.g., [3,4].

$\mathrm{H}_{2} \mathrm{O}+\mathrm{CO} \leftrightarrow \mathrm{H}_{2}+\mathrm{CO}_{2}$

If the $\mathrm{CO}_{2}$ is vented to the atmosphere, it can be claimed that the biomass feedstock is not utilized to its full extent because the carbon in the vented $\mathrm{CO}_{2}$ could in theory be used to produce more carbon-rich biofuel. One way of increasing the utilization of the biomass feedstock, and thereby increasing the 
production of biofuel, is by the addition of hydrogen to the biorefinery. The added hydrogen is used to adjust the $\mathrm{H}_{2}$ /CO-ratio in the syngas before chemical synthesis, and it therefore potentially eliminates the need for a water gas shift reactor and $\mathrm{CO}_{2}$ capture. By adding hydrogen to the biorefinery, it is in theory possible to convert all of the carbon in the biomass feedstock to carbon stored in the biofuel product. The added hydrogen could be produced by the electrolysis of water/steam using non-fossil or renewable electricity. A benefit of incorporating the electrolysis of water/steam into a biorefinery is the co-production of oxygen from the electrolysis. This oxygen is needed for the gasification of the biomass feedstock, and the electrolyser therefore eliminates the need for an oxygen plant. A thermochemical biorefinery using electrolytic hydrogen is termed an "advanced thermochemical biorefinery" in this paper, and in Fig. 1, a schematic of such a plant is shown and compared to a "conventional" thermochemical biorefinery.

Adding electrolysis to a biorefinery only makes sense if the price of electricity is frequently lower than the price of biomass (per energy unit). The future prices of biomass and electricity are uncertain and difficult to predict, but if the demand for biomass for energy purposes increases more than the supply, the biomass price will increase. A biorefinery that could utilize all of the carbon in the biomass could therefore be both economically attractive and environmentally attractive (as less biomass is used for the same amount of biofuel produced). The price of electricity typically varies over a daily cycle, so the electrolyser could therefore operate when electricity prices are low, e.g., during the night time. For this to work in connection with a biorefinery, the underground gas storage of hydrogen and oxygen is desirable to enable the biorefinery to operate for a maximum number of operating hours and not just when the electrolyser is operating ${ }^{1}$. It is important to note that when the operating hours of the electrolyser are reduced, the electrolyser capacity must be increased, which means higher capital costs. In some future energy systems, the installed capacity of fluctuating renewables, such as wind and solar, is expected to be significant, leading to a requirement for flexible electricity consumers with a high capacity, both in terms of power and energy $[5,6]$. A water/steam electrolysis plant is such a consumer [7]. The hydrogen generated by the electrolyser could be converted back to electricity when the demand for electricity is high, but it could be more economically attractive as well as more environmentally attractive to have the opportunity to use the hydrogen for fuel production ${ }^{2}$. If the hydrogen is used for fuel production, a link has been created between the power grid and the transportation sector. Linking different energy systems into one big "smart energy system" consisting of the power grid, gas grid, the transportation sector and the district heating system has been proposed by, e.g., [5,6]. This makes it possible to substitute fossil energy with renewable electricity in the transportation sector, something that is otherwise only possible using electric vehicles and hydrogen vehicles (via electrolysis).

\footnotetext{
${ }^{1}$ Other biorefinery types could avoid the use of underground gas storage. Two examples: Example 1: using a gasifier that can operate both on air and oxygen. When electricity prices are low, the electrolyser produces oxygen for the gasifier and hydrogen for the syngas. The gasifier will then produce a nitrogen-free syngas that is suited for fuel production. When electricity prices are high, the electrolyser does not operate. The gasifier will then be air-blown, and the gas from the gasifier is used for electricity production in a combined cycle (BIGCC - biomass-integrated gasification combined cycle). This will ensure that the high capital cost gasifier operates for a maximum number of operating hours, but the fuel production section will only operate when the electrolyser operates (when electricity prices are low). The compression of air instead of oxygen to the gasifier will also be costly, but it will not be an issue if the gasifier pressure is limited to the gas turbine pressure because the air consumption of the gas turbine will be lowered. Example 2: adding an electrolyser to a conventional thermochemical biorefinery as an add-on. This means that the biorefinery will also include a cryogenic oxygen plant and water gas shift (carbon capture is present in the advanced biorefinery if $\mathrm{CO}_{2}$ is used for feeding the biomass to the gasifier). The plant can then operate as both a "conventional" biorefinery and as an "advanced" biorefinery. The disadvantages of such a biorefinery are the added capital cost and that the fuel synthesis capacity must be set based on the requirements of the "advanced" biorefinery (approximately twice the capacity of a conventional biorefinery).

2 This is assuming that the transportation sector is not hydrogen based (using hydrogen fuel cell vehicles).
} 
Previous work on using electrolytic hydrogen together with biomass gasification for fuel production includes [8-13]. In [8-10,12], the biofuel is methanol. In [11], the biofuel is synthetic natural gas (SNG). In [13], it is Fischer-Tropsch fuel. The novelty of the present paper is the detailed design and analysis of the proposed biorefineries as well as using the electrolytic hydrogen for chemically quenching the hot gas from an entrained flow gasifier. This quenching creates a more suitable syngas for methanol synthesis by converting an appropriate amount of $\mathrm{CO}_{2}$ to $\mathrm{CO}$ via the reverse water gas shift reaction (RWGS). The analysis in the paper also adds to the knowledge available in the literature by showing the impact of integrating a torrefaction process in a biorefinery. The impact is presented with respect to biorefinery design, energy and carbon utilization.

The two biorefineries investigated in this paper both use torrefied woody biomass as the input to the gasifier because this enables the use of commercial coal gasification equipment $[14,15]$. One of the biorefineries investigated also incorporates "integrated torrefaction", which integrates biomass torrefaction and entrained flow gasification of the torrefied biomass. This integration was proposed in [15] and is based on using the volatiles from the torrefaction for a chemical quench of the hot gas from the entrained flow gasifier. This increases the "overall cold gas efficiency" of the syngas production significantly. In [16], this "integrated torrefaction" is investigated in more detail.

The present paper presents the conceptual design and thermodynamic analysis of two thermochemical biorefineries, both with integrated water electrolysis. One of the biorefineries operates on torrefied biomass pellets, and the other operates on wood chips using "integrated torrefaction". The two biorefineries are compared with two similar biorefineries without integrated water electrolysis. These two "conventional" biorefineries are presented in detail in [16].

\section{Design of the biorefineries}

The design of the biorefineries is based on the design presented in [16]. So as not to reproduce the full description in this paper, only a brief description is given along with Table 1 , which presents the key process design parameters used in the modeling. Two processes were, however, not employed in the previous paper and are therefore presented below. The biorefineries were modelled in Aspen Plus and an in-house modeling tool called DNA [17] ${ }^{3}$.

Fig. 2 and Fig. 3 show simplified flow sheets of the two modelled biorefineries. The main processes in the two biorefineries are the same and start with the pressurized oxygen-blown gasification of a torrefied biomass powder. In the biorefinery based on wood chips, the torrefaction of the biomass feed occurs on-site. The oxygen for the gasification is supplied by the water electrolysis. The hot gas from the gasifier is cooled by a chemical quench with either electrolytic hydrogen or volatiles from the upstream torrefaction. The gas is then further cooled before it is conditioned by the removal of sulfur and $\mathrm{CO}_{2}$. The extracted $\mathrm{CO}_{2}$ is used for feeding the biomass to the pressurized gasifier. The conditioned syngas is mixed with electrolytic hydrogen to produce a syngas with an appropriate $\mathrm{H}_{2} / \mathrm{CO}$-ratio for methanol synthesis. The syngas is then pressurized and converted to methanol in the methanol reactor. The product gas from the methanol reactor is cooled to ambient temperature to condense out the produced methanol. $97 \%$ of the unconverted syngas is recirculated to the reactor, while the rest is used for electricity production in a gas turbine. The crude methanol product from the reactor is sent to distillation to first remove absorbed gases and then remove water to produce a high-purity methanol

\footnotetext{
${ }^{3}$ The gasification part is modelled in DNA (Dynamic Network Analysis) and the rest of the biorefinery in Aspen Plus. DNA is used for the gasification part because it has a better solids handling than Aspen Plus. The property methods used in Aspen Plus are PR-BM (Peng-Robinson with Boston-Mathias alpha function) for the syngas processing, SR-POLAR (Schwarzentruber and Renon) for the methanol reactor loop and the distillation, and STEAMNBS for the integrated steam plant.
} 
product. An integrated steam cycle utilizes the waste heat available in the biorefinery for electricity production.

\section{Electrolysis of water and gas storage}

Alkaline water electrolysis with an LHV efficiency from electricity to hydrogen of $70 \%$ is used $[7,8]$. The water electrolysis is performed at 30 bar [7] to minimize costly gas compression. Other electrolyser types include PEM (proton exchange membrane) and SOEC (solid oxide electrolyser cell). SOEC steam electrolysis can achieve an LHV efficiency from electricity to hydrogen of $83 \%$ (cell voltage of $1.51 \mathrm{~V}$ ) $[18,19]$, and if steam can be generated by waste heat instead of electricity, the LHV efficiency from electricity to hydrogen can increase to $97 \%$ (cell voltage of $1.30 \mathrm{~V}$ ) $[18,19]$. SOEC steam electrolysis is, however, still in the research/development phase and was therefore not used in the present study. The hydrogen and oxygen produced by the water electrolysis is compressed to 200 bar $^{4}$ and stored underground. Because of the large plant size, only underground gas storage is an economically viable storage technology [20].

\section{Chemical quench}

Two types of chemical quench are used to cool the gas from the pressurized entrained flow gasifier. In the biorefinery based on torrefied wood pellets, a hydrogen quench is used to convert an appropriate amount of $\mathrm{CO}_{2}$ to $\mathrm{CO}$ via the reverse water gas shift reaction (RWGS). This creates a syngas with a low $\mathrm{CO}_{2}$ content, which is more suitable for methanol synthesis ${ }^{5}$.

In the biorefinery based on wood chips, a chemical quench using the volatiles from the upstream torrefaction of biomass is employed to increase the overall cold gas efficiency of the gasifier. It is assumed that the volatiles are converted to $\mathrm{CO}, \mathrm{H}_{2}, \mathrm{H}_{2} \mathrm{O}$ and $\mathrm{CO}_{2}$ due to the high temperature of the gas from the gasifier [15].

For both types of chemical quench, it is assumed that the water gas shift reaction is at chemical equilibrium after the quench. This assumption is appropriate to make at high temperatures. The temperature after the quench with the volatiles is, however, only $858^{\circ} \mathrm{C}$.

\section{Results}

The results of the thermodynamic modeling and analysis of the two thermochemical biorefineries are presented in the following. In Fig. 4 and Fig. 5, the detailed flow sheets of the two biorefineries are presented, showing mass and energy flows throughout the plant. In Table 2 and Table 3, the compositions of the key mass flows in the two biorefineries are given. Table 4 summarizes the main results, including the key energy efficiencies and energy ratios. One of the most important energy ratios is the biomass to methanol energy ratio. This ratio is calculated to be $136 \%$ for the plant based on wood chips (integrated torrefaction) and 101\% for the biorefinery based on torrefied biomass pellets (external torrefaction). This shows that the product methanol contains more energy than the biomass feed. This is, of course, only possible because hydrogen from water electrolysis is supplied to the syngas. The total efficiencies (biomass + net electricity to methanol) are calculated to be $62 \%$ (integrated torrefaction) and $56 \%$ (external torrefaction). The main reason for the higher energy efficiency and energy ratio of the plant using integrated torrefaction is the higher biomass to syngas efficiency ( $86 \%$ vs. $63 \%$ ) that is achieved by using integrated torrefaction instead of external torrefaction. The syngas to methanol energy efficiencies are very similar ( $80 \%$ vs. $81 \%$ ) even though the $\mathrm{CO}_{2}$ content in the syngas is much

\footnotetext{
${ }^{4}$ In practice, the gas pressure in the storage will vary from the operating pressure of the gasifier, which is 45 bar, to the maximum storage pressure of 200 bar. When the electrolyser operates, the gas needed in the biorefinery will only be compressed to the gasifier pressure. The surplus gas will then be compressed further to the storage pressure and stored underground. This surplus gas is then used in the biorefinery when the electrolyser is not operating.

${ }^{5}$ Discussed in section 4 (discussion)
} 
higher in the plant using integrated torrefaction ( $13.1 \%$ vs. $3 \%$ in the inlet to the methanol reactor). A high $\mathrm{CO}_{2}$ content in the syngas will typically lead to a somewhat higher hydrogen requirement according to eq. 2-3. The results, however, show that the hydrogen to methanol energy ratio is only slightly higher in the plant based on external torrefaction (164\% vs. $166 \%$ ). This is due to the hydrogen consumption in the hydrogen quench used in the plant based on external torrefaction and because the amount of $\mathrm{CO}_{2}$ in the purge gas from the synthesis reactor is almost twice as high in the plant based on integrated torrefaction.

$$
\begin{aligned}
& 2 \mathrm{H}_{2}+\mathrm{CO} \leftrightarrow \mathrm{CH}_{3} \mathrm{OH} \\
& 3 \mathrm{H}_{2}+\mathrm{CO}_{2} \leftrightarrow \mathrm{CH}_{3} \mathrm{OH}+\mathrm{H}_{2} \mathrm{O}
\end{aligned}
$$

The net electricity to methanol ratio ( $111 \%$ vs. $121 \%)$ does not follow the trend of the hydrogen to methanol ratio, despite $94-95 \%$ of the electricity consumption being for the electrolyser. This is because the electricity production of the integrated steam cycle is much higher in the plant based on external torrefaction due to the heat requirements for torrefaction and steam drying in the plant based on integrated torrefaction, which leaves only a small amount of waste heat for the integrated steam cycle. The on-site electricity production is, however, high enough to cover the electricity consumption when the electrolysis is not operating. This is important because when the electrolysis is not operating, the electricity prices are high.

Based on these results, it can be stated that switching from the more conventional external torrefaction to the more advanced integrated torrefaction will increase the net electricity consumption by $8 \mathrm{~kJ}$ (from $79 \mathrm{~kJ}$ to $87 \mathrm{~kJ}$ ) per $100 \mathrm{~kJ}$ of methanol produced but will also decrease the biomass consumption by $25 \mathrm{~kJ}$ (from $99 \mathrm{~kJ}$ to $73 \mathrm{~kJ}$ ) per $100 \mathrm{~kJ}$ of methanol produced ${ }^{6}$.

The chemical energy flows in the two biorefineries can be observed in Fig. 6 . The figure also includes two similar plants without electrolysis for comparison (from [16]). With respect to the two plants in this paper, the figure shows how the biomass to methanol energy ratios of $136 \%$ and $101 \%$ are derived because all flows are normalized by the chemical energy flow of the input biomass. It also shows how the biomass to syngas energy efficiencies of $86 \%$ and $63 \%$ appear. It is clear that the main reason for the difference in energy ratios as well as in energy efficiencies is the conversion heat loss in the external torrefaction ${ }^{7}$. The figure also shows that only $28 \%(17 \% / 61 \%)$ of the hydrogen produced by the electrolyser in the plant based on external torrefaction is needed for the chemical quench. If all of the hydrogen had been used in the quench, not enough $\mathrm{CO}_{2}$ would be left in the syngas ${ }^{8}$. The chemical energy flow in the purge gas from the methanol reactor loop can be observed to be more than twice as high for the plant based on integrated torrefaction; this is mainly due to the higher $\mathrm{CO}_{2}$ content of the syngas but also simply because the chemical energy flow of syngas to the reactor is $36 \%$ higher. Upon comparison with the plants without electrolysis, it can be observed that adding electrolytic hydrogen more than doubles the methanol output per biomass input. The increase is greatest for the plant with integrated torrefaction because the purge gas flow to the gas turbine was high (7\%) in the plant without electrolysis to cover the on-site electricity consumption. The loss occurring in the water

\footnotetext{
${ }^{6}$ The electricity consumption should not be converted to primary energy (by using a biomass to electricity efficiency of a biomass power plant), which is otherwise often done in these types of analyses. The reason is that these types of plants are only relevant if the electricity is supplied by renewables such as wind and solar. Electricity is therefore considered to be primary energy.

${ }^{7}$ In external torrefaction, the volatiles are combusted and the heat used for torrefaction and drying of the biomass.

${ }^{8} \mathrm{CO}_{2}$ is needed for the following: 1. feeding the biomass to the gasifier (the $\mathrm{CO}_{2}$ is captured from the syngas) and 2. ensuring optimal catalytic activity in the methanol reactor ( $\mathrm{C} \mathrm{CO}_{2}$ content of approx. $3 \%$ is optimal)
} 
gas shift reactor (3\%) is avoided when adding electrolytic hydrogen because it is not necessary to convert $\mathrm{CO}$ to $\mathrm{H}_{2}$ when $\mathrm{H}_{2}$ is added.

Fig. 7 shows the carbon flows in the two biorefineries and compares them with two similar plants without electrolysis. With respect to the two plants in this paper, the figure shows that in the plant using integrated torrefaction, almost all of the carbon in the biomass ends up as carbon stored in the produced biofuel (96\%). The biomass to methanol energy ratio of $136 \%$ for the plant using integrated torrefaction (Fig. 6) can therefore not be much higher. In the plant using external torrefaction, $77 \%$ of the carbon in the biomass ends up as carbon stored in the produced biofuel because a lot of carbon is emitted from the external torrefaction process. The figure also shows how much $\mathrm{CO}_{2}$ is captured in the AGR and used for feeding the biomass to the gasifier ( $8 \% / 10 \%)$. The amount of $\mathrm{CO}_{2}$ needed for the feeding is lower in the plant using integrated torrefaction because the mass flow of biomass to the gasifier is lower.

With respect to the plants without electrolysis, it can be observed that most of the carbon in the biomass ends up as $\mathrm{CO}_{2}$ vented from the plants instead of carbon stored in the produced biofuel.

\section{Discussion}

Each of the four biorefineries discussed above (in connection with Fig. 6 and Fig. 7) could be attractive given the right situation or given the right prerequisites. In Table 5, the main prerequisites are stated ${ }^{9}$. The demand for biomass for energy purposes is expected to increase greatly in the future transition to renewable energy. To limit the biomass demand for fuel production, an incentive could be made to increase the fuel yield per biomass input. Such an incentive would favor the plants with electrolysis and especially favor the biorefinery with integrated torrefaction.

Below, two relevant aspects of the investigated biorefineries are discussed. These are as follows: 1 . converting $\mathrm{CO}_{2}$ to $\mathrm{CO}$ before methanol synthesis and 2. changes in the plant design and energy efficiency due to the addition of electrolytic hydrogen.

\section{Converting $\mathrm{CO}_{2}$ to $\mathrm{CO}$ before methanol synthesis}

In the biorefinery using external torrefaction, a chemical quench with hydrogen is used to convert some of the $\mathrm{CO}_{2}$ in the syngas to $\mathrm{CO}$. This conversion has two benefits: 1 . Higher per-pass conversion in the methanol reactor, thus resulting in a lower capacity reactor and a smaller purge gas loss 2 . Lower water production in the methanol reactor (eq. 2-3), thus lowering the heat requirement of the distillation part. Table 6 shows how much of the carbon in the syngas is in the form of $\mathrm{CO}$ for the two biorefineries investigated in this paper and for a modified version of the biorefinery based on integrated torrefaction. It can be observed how this $\mathrm{CO}$ fraction changes from the gasifier exit to the inlet of the methanol reactor. The benefits of converting $\mathrm{CO}_{2}$ to $\mathrm{CO}$ before methanol synthesis (mentioned above) are also quantified in the table.

Instead of using a hydrogen quench to convert $\mathrm{CO}_{2}$ to $\mathrm{CO}$, solid oxide electrolysis cells (SOEC) could be used. The SOEC would then receive the pure $\mathrm{CO}_{2}$ stream from the $A G R$ and return a $\mathrm{CO}$-rich stream before or after the AGR. This is especially useful in cases where the hydrogen quench cannot convert the desired amount of $\mathrm{CO}_{2}$ to $\mathrm{CO}$. This is true for the biorefinery with integrated torrefaction and is also true

\footnotetext{
${ }^{9}$ Other important factors include the following: 1 . Capital cost of the electrolyser and gasifier; if the capital cost of the electrolyser multiplied by a factor $F(F=$ capacity factor of gasifier/capacity factor of electrolyser, an example could be: $F=$ $90 \% / 45 \%=2$ ) is lower than the capital cost of the gasifier (per syngas production capacity), it would favor the plants with an electrolyser. 2. Capital cost and societal acceptance of underground gas storage of $\mathrm{H}_{2}$ and $\mathrm{O}_{2}-$ as mentioned in the introduction, it is possible to design a biorefinery with integrated electrolysis that is not dependent on gas storage.
} 
for low-temperature gasification in general because the $\mathrm{CO}_{2}$ content increases when the gasification temperature is decreased (water gas shift reaction, eq. 1$)^{10}$.

\section{Changes in heat integration and total energy efficiency due to the addition of electrolytic hydrogen} With respect to the change in the plant total energy efficiency when adding electrolytic hydrogen, Fig. 8 shows that at an electrolyser energy efficiency of $70 \%$, the change is small; a small decrease is observed for the plant with integrated torrefaction (from 63\% to 62\%), and a small increase is observed for the plant with external torrefaction (from $53 \%$ to $56 \%$ ). The small decrease observed for the plant with integrated torrefaction is mainly due to the overall cold gas efficiency of the gasifier being higher than the electrolyser efficiency ( $86 \%$ vs. $70 \%$ ), while the opposite is true for the plant with external torrefaction.

If high temperature steam electrolysis was used instead of water electrolysis, a much higher electrolyser efficiency could be achieved (95-98\%, as discussed in section 2 ). This would increase the total energy efficiency of the plants substantially (Fig. 8).

The changes in heat integration due to the addition of electrolytic hydrogen are most noticeable in the plant based on integrated torrefaction. The heat integration becomes noticeably simpler in this plant because the available waste heat from the methanol reactor almost doubles (from $48 \mathrm{MW}$ th to 93 MWth $)^{11}$ because the methanol production more than doubles. This waste heat stream can then cover the heat demand for biomass drying ( $75 \mathrm{MWth}$ ). The heat requirement for distillation also more than doubles with the addition of electrolytic hydrogen. This has, however, a very limited impact on the plant based on integrated torrefaction because the waste heat available from condensing the produced steam from the steam dryer can cover most of the heat demand (the heat demand of the methanol column reboiler).

\section{Conclusion}

A thermodynamic analysis of two thermochemical biorefineries integrating the electrolysis of water has been performed. The analysis showed that the biorefinery with integrated torrefaction has a higher biomass to methanol energy ratio ( $136 \%$ vs. $101 \%$ ) as well as a higher total energy efficiency ( $62 \%$ vs. $56 \%)$. The difference in energy performance is mainly due to the difference in the utilization of the volatiles from torrefaction. In the plant based on integrated torrefaction, the volatiles are converted to syngas and thereafter to product methanol, while in the plant based on external torrefaction, the volatiles are combusted to supply heat for the drying and torrefaction of the biomass feedstock. Although the total energy efficiency is lower for the plant based on external torrefaction, the net electricity consumption per methanol unit is also lower. This is because more waste heat is available for the integrated steam cycle because the heat requirement for biomass drying and torrefaction is not covered by waste heat but by combustion of the volatiles. Based on the results, it can be stated that switching from the more conventional external torrefaction to the more advanced integrated torrefaction will increase the net electricity consumption by $8 \mathrm{~kJ}$ per $100 \mathrm{~kJ}$ of methanol produced but will also decrease the biomass consumption by $25 \mathrm{~kJ}$ per $100 \mathrm{~kJ}$ of methanol produced.

A carbon analysis showed that $96 \%$ of the carbon in the biomass feedstock was converted to carbon in the product methanol in the biorefinery with integrated torrefaction. This means that the methanol

\footnotetext{
${ }^{10} \mathrm{Gas}$ from the Two-Stage Gasifier [27] has a $\mathrm{CO} /\left(\mathrm{CO}+\mathrm{CO}_{2}\right)$ fraction of $65 \%$. If this gasifier was used for methanol production as described in this paper, the $\mathrm{CO} /\left(\mathrm{CO}+\mathrm{CO}_{2}\right)$ fraction would be very low at the inlet to the methanol reactor because that $\mathrm{CO}_{2}$ is not used for feeding the biomass, so no AGR is used. If an SOEC would be used to convert some of the $\mathrm{CO}_{2}$ to $\mathrm{CO}$, then an $\mathrm{AGR}$ would be needed, unless the SOEC would operate directly on the gas from the gasifier (after cleaning the gas from particles, sulfur and perhaps other impurities).

${ }^{11}$ This can be seen by comparing the two flow sheets (with electrolysis: Fig. 4, without electrolysis: Fig. 8 in [16])
} 
yield per biomass input is close to the theoretical maximum. The biomass to methanol energy ratio of $136 \%$ is therefore also close to the theoretical maximum.

By comparing the two biorefineries to two identical biorefineries without electrolysis, it is concluded that the biorefinery with integrated torrefaction benefits most by the integration of electrolysis. This is because two important issues are solved by the integration of electrolysis within this biorefinery: 1 . The purge gas flow that is converted to electricity in the gas turbine can be minimized because the plant is not required to cover the on-site electricity consumption when electrolysis is integrated. 2 . The heat integration becomes much simpler because more waste heat is available from the methanol reactor due to a $118 \%$ increase in methanol production. Assuming that thermochemical biorefineries integrating electrolysis will be built in the future, integrated torrefaction would therefore be more attractive to use in these types of biorefineries compared to biorefineries without electrolysis.

Thermochemical biorefineries integrating electrolysis could be attractive from an environmental perspective because of the very high fuel yield per biomass input, which results in a low consumption of the limited biomass resource. Because the plants can provide a flexible electricity demand, they can also help in balancing an electricity grid with a large share of fluctuating renewables such as wind and solar. This also enables renewable energy from, e.g., wind, to be utilized in the transportation sector, which would otherwise only be possible by electric vehicles or hydrogen-fueled vehicles. 


\section{References}

[1] Balan V, Chiaramonti D, Kumar S. Review of US and EU initiatives toward development, demonstration, and commercialization of lignocellulosic biofuels. Biofuels Bioprod Biorefining 2013;7(6):732-59.

[2] Haro P, Ollero P, Villanueva Perales AL, Vidal-Barrero F. Potential routes for thermochemical biorefineries. Biofuels Bioprod Biorefining 2013;7(5):551-72.

[3] Larson ED, Williams $\mathrm{RH}$, Jin $\mathrm{H}$. Fuels and electricity from biomass with $\mathrm{CO} 2$ capture and storage. In: Proceedings of the 8th international conference on greenhouse gas control technologies, Trondheim, Norway, 2006.

[4] Clausen LR, Elmegaard B, Houbak N. Technoeconomic analysis of a low CO 2 emission dimethyl ether (DME) plant based on gasification of torrefied biomass. Energy 2010;35(12):4831-42.

[5] Mathiesen BV, Lund H, Karlsson K. 100\% Renewable energy systems, climate mitigation and economic growth. Appl Energy 2011;88(2):488-501.

[6] Lund H, Andersen AN, Ostergaard PA, Mathiesen BV, Connolly D. From electricity smart grids to smart energy systems - A market operation based approach and understanding. Energy 2012;42(1):96102.

[7] Mathiesen B, Ridjan I, Connolly D, Nielsen M, Hendriksen P, Mogensen M et al. Technology data for high temperature solid oxide electrolyser cells, alkali and PEM electrolysers. Report: ISBN:978-87-9140446-7. Aalborg University: Department of Development and Planning, 2013. http://vbn.aau.dk/files/80222058/Technology data for SOEC alkali and PEM electrolysers.pdf.

[8] Clausen LR, Houbak N, Elmegaard B. Technoeconomic analysis of a methanol plant based on gasification of biomass and electrolysis of water. Energy 2010;35(5):2338-47.

[9] Specht M, Bandi A, Baumgart F, Muray CM, Gretz J. Synthesis of methanol from biomass/CO2 resources. In: Greenhouse Gas Technologies. Amsterdam, 1999, p. 723-727. http://lampopumput.info/foorumi/index.php?action=dlattach;topic=4175.0;attach=6781.

[10] Mignard D, Pritchard C. On the use of electrolytic hydrogen from variable renewable energies for the enhanced conversion of biomass to fuels. Chem Eng Res Design 2008;86(5):473-87.

[11] Gassner M, Maréchal F. Thermo-economic optimisation of the integration of electrolysis in synthetic natural gas production from wood. Energy 2008;33(2):189-98.

[12] Ouellette N, Rogner H-, Scott DS. Hydrogen from remote excess hydroelectricity. Part II: Hydrogen peroxide or biomethanol. Int J Hydrogen Energy 1995;20(11):873-80.

[13] Bernical Q, Joulia X, Noirot-Le Borgne I, Floquet P, Baurens P, Boissonnet G. Sustainability Assessment of an Integrated High Temperature Steam Electrolysis-Enhanced Biomass to Liquid Fuel Process. Ind Eng Chem Res 2013;52(22):7189-7195. 
[14] Weiland F, Nordwaeger M, Olofsson I, Wiinikka H, Nordin A. Entrained flow gasification of torrefied wood residues. Fuel Process Technol 2014;125:51-58.

[15] Prins MJ, Ptasinski KJ, Janssen FJJG. More efficient biomass gasification via torrefaction. Energy 2006;31(15):3458-70.

[16] Clausen LR. Integrated torrefaction vs. external torrefaction - A thermodynamic analysis for the case of a thermochemical biorefinery. Energy 2014;77:597-607.

[17] Elmegaard B, Houbak N. DNA - a general energy system simulation tool. In: SIMS 2005, 46th conference on simulation and modeling. Trondheim, Norway, 2005, p. 43-52.

http://www.scansims.org/sims2005/SIMS2005 16.pdf.

[18] Jensen SH, Larsen PH, Mogensen M. Hydrogen and synthetic fuel production from renewable energy sources. Int J Hydrogen Energy 2007;32(15):3253-7.

[19] The Danish Energy Agency and Energinet.dk. Technology Data for Energy Plants - Generation of Electricity and District Heating, Energy Storage and Energy Carrier Generation and Conversion. Report, 2012. ISBN: 978-87-7844-931-3.

http://www.energinet.dk/SiteCollectionDocuments/Danske\%20dokumenter/Forskning/Technology dat a for energy plants.pdf.

[20] Amos WA. Cost of storing and transporting hydrogen. Report: NREL/TP-570-25106. Golden, Colorado, USA: National Renewable Energy Laboratory, 1998.

http://www.nrel.gov/docs/fy99osti/25106.pdf.

[21] Kiel JHA, Verhoeff F, Gerhauser H, Meuleman B. BO2-technology for biomass upgrading into solid fuel - pilot-scale testing and market implementation. In: Proceedings for the 16th European Biomass Conference \& Exhibition. Valencia, Spain, 2008, p. 48-53. http://www.ecn.nl/publications/.

[22] Van Der Drift A, Boerrigter H, Coda B, Cieplik MK, Hemmes K. Entrained-flow gasification of biomass; Ash behaviour, feeding issues, system analyses. Report: ECN-C--04-039. Petten, The Netherlands: ECN, 2004. http://www.ecn.nl/publications/.

[23] van der Ploeg HJ, Chhoa T, Zuideveld PL. The Shell Coal Gasification Process for the US Industry. In: Proceedings for the Gasification Technology Conference. Washington DC, USA, 2004.

[24] Kreutz TG, Larson ED, Liu G, Williams RH. Fischer-Tropsch Fuels from Coal and Biomass. Report. Princeton, New Jersey: Princeton Environmental Institute, Princeton University, 2008.

http://www.princeton.edu/pei/energy/publications/texts/.

[25] PIX Pellet Nordic Index. Web Page: http://www.foex.fi/index.php?page=biomass (accessed November 2014).

[26] Nord Pool Spot. Web Page: http://www.nordpoolspot.com/Market-data1/Elspot/AreaPrices/ALL1/Yearly/?view=chart (accessed November 2014). 
[27] Clausen LR, Elmegaard B, Ahrenfeldt J, Henriksen U. Thermodynamic analysis of small-scale dimethyl ether (DME) and methanol plants based on the efficient two-stage gasifier. Energy 2011;36(10):5805-14. 


\section{Conventional thermochemical biorefinery:}

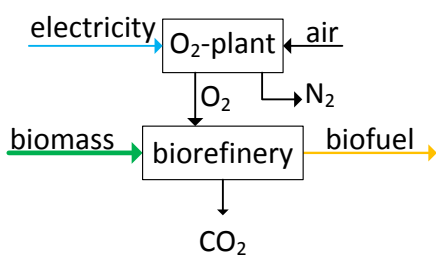

Advanced thermochemical biorefinery:

\begin{tabular}{|c|c|c|}
\hline electricity & electrolyser & water/steam \\
\hline & $\dashv \mathrm{O}_{2} \quad \mathrm{H}_{2}$ & \\
\hline
\end{tabular}

Fig. 1. Schematics of a conventional thermochemical biorefinery (top) and a thermochemical biorefinery with an integrated water/steam electrolyser (bottom). Note: The thickness of the lines for electricity and biofuel indicate the difference between the two biorefineries in electricity consumption and biofuel production. 


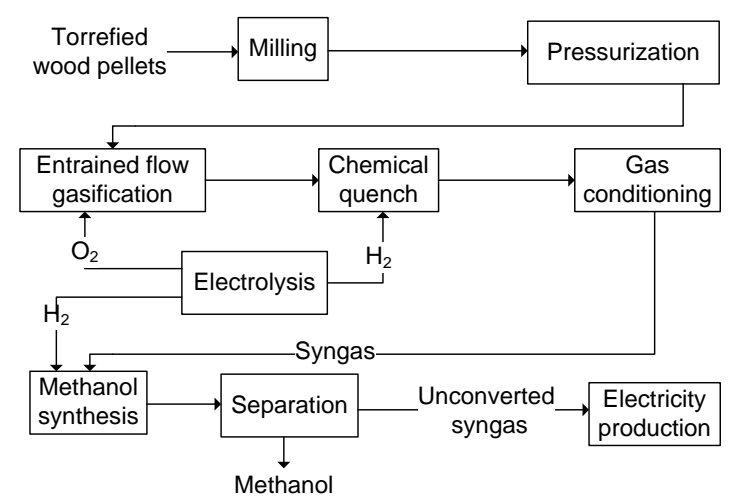

Fig. 2. Simplified flow sheet of the methanol plant based on torrefied wood pellets (external torrefaction) 


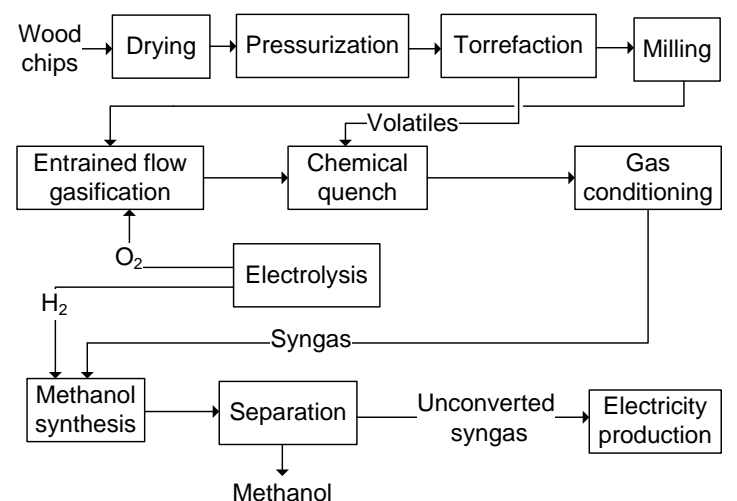

Fig. 3. Simplified flow sheet of the methanol plant based on wood chips (integrated torrefaction) 




Fig. 4. Detailed flow sheet of the methanol plant based on wood chips (integrated torrefaction). The heat integration as well as the power consumption and production are shown in the flow sheet. Note: The underground storages of hydrogen and oxygen are assumed to be adiabatic. 
Net electricity consumption: 2324 MWe

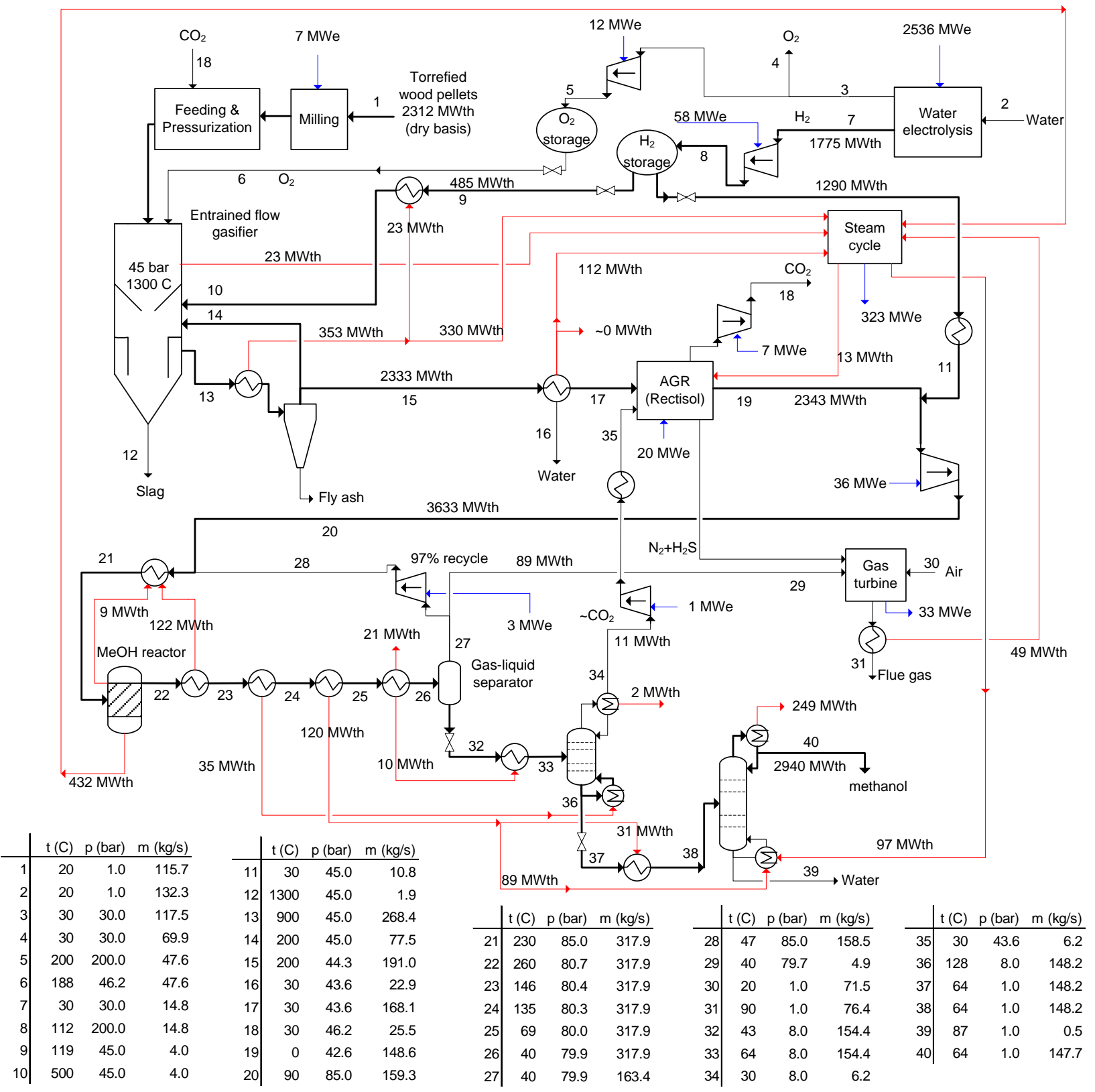

Fig. 5. Detailed flow sheet of the methanol plant based on torrefied wood pellets (external torrefaction). The heat integration as well as the power consumption and production are shown in the flow sheet. Note 1: the temperature in the gasifier after the hydrogen quench is $1164^{\circ} \mathrm{C}$. Note 2 : The underground storages of hydrogen and oxygen are assumed to be adiabatic. 


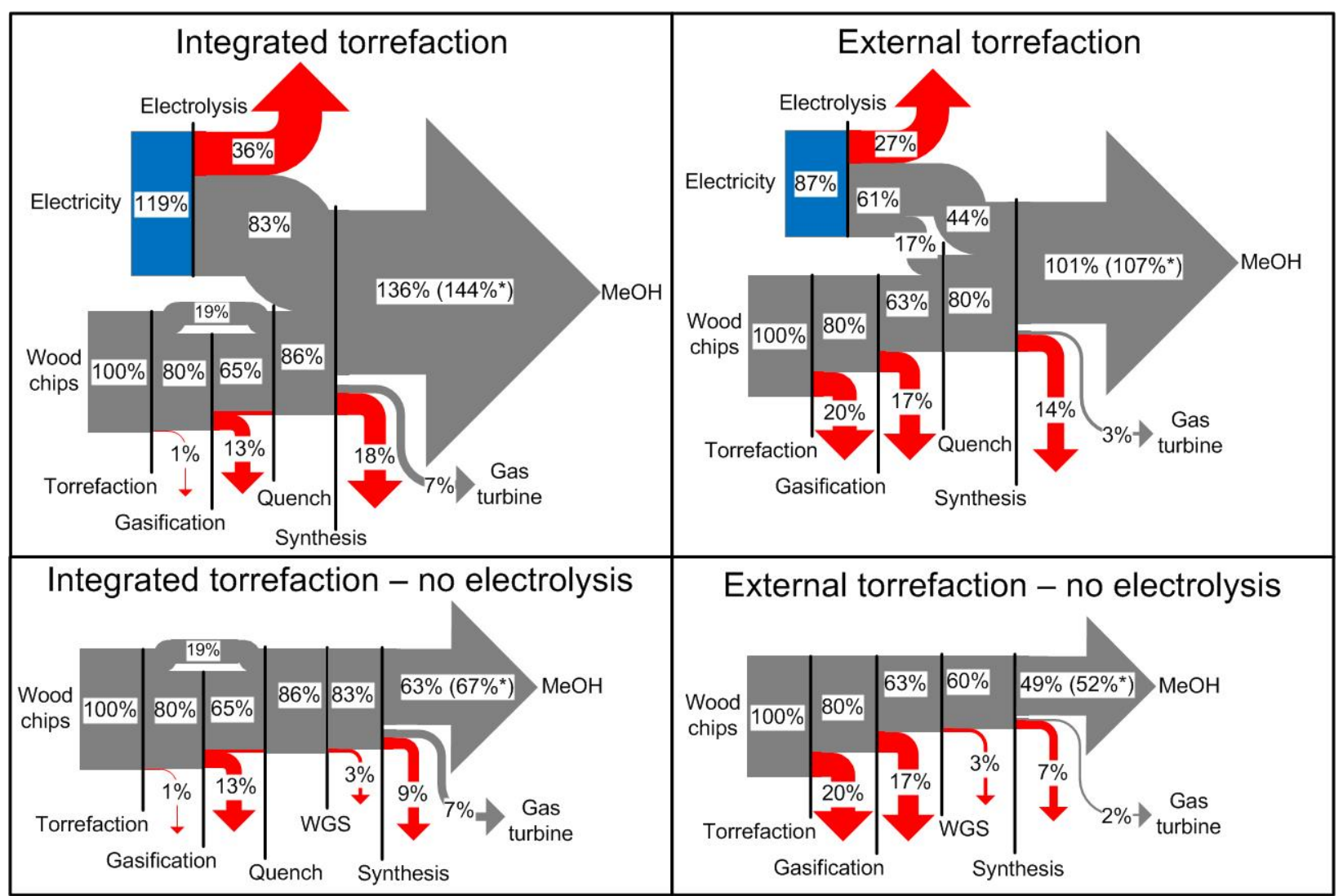

Fig. 6. Chemical energy flows (LHV-dry) and conversion heat losses in the two biorefineries (top) compared with the same biorefineries without electrolysis (bottom - from [16]). All flows are normalized to the flow of chemical energy in the input wood chips. Note: the torrefaction process occurs outside the plant for "external torrefaction". * The value given in parentheses is the energy value of methanol in the gas state (LHV). If this value is used, the width of the arrows before and after synthesis would be equal. 


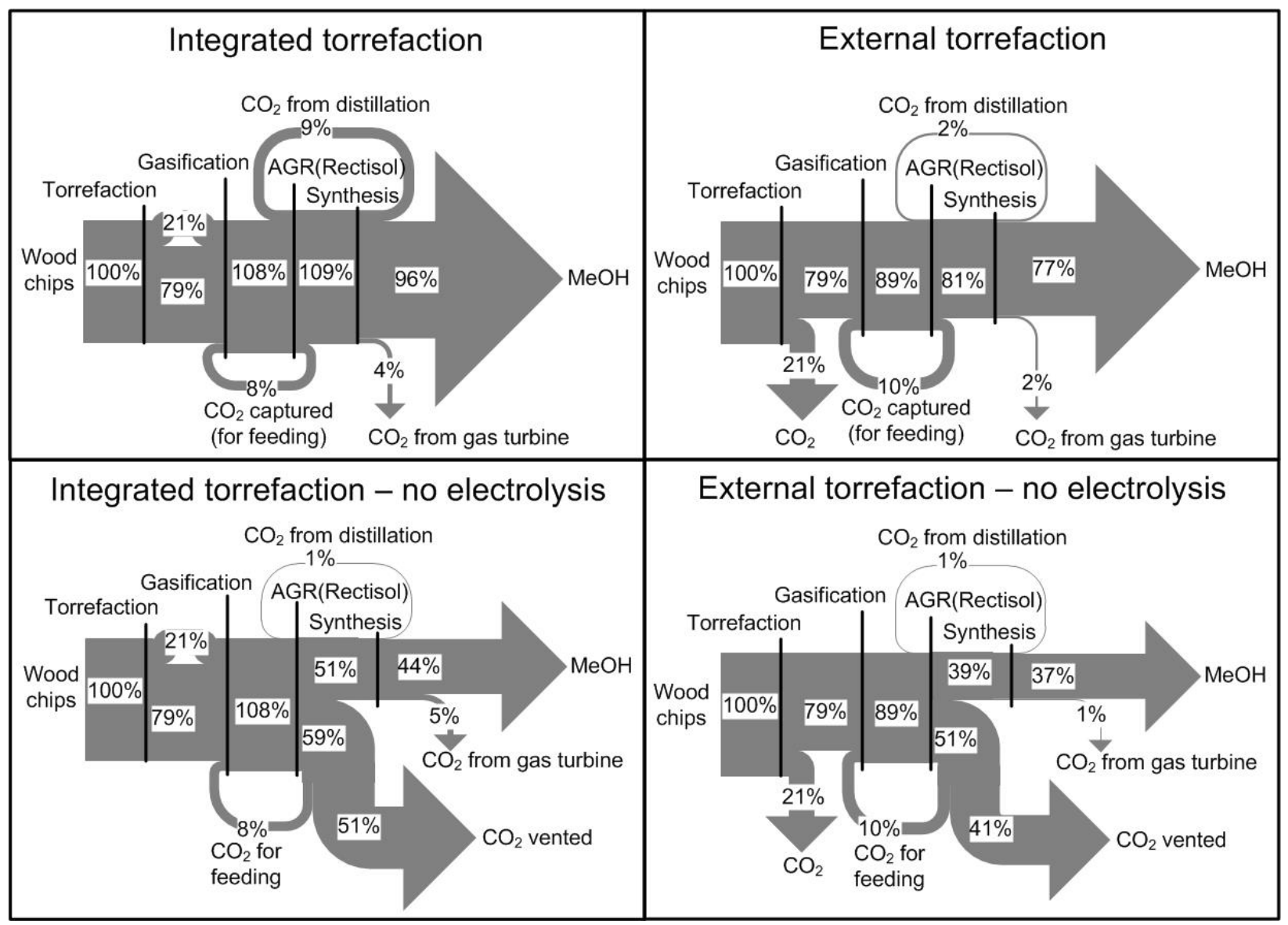

Fig. 7. Carbon flows in the two biorefineries (top), compared with the same biorefineries without electrolysis (bottom - from [16]). 




Fig. 8. Total efficiencies for the two biorefineries as a function of the electrolyser energy efficiency (electricity to hydrogen). The biorefineries with no electrolysis are shown for comparison. Note: the total efficiency is defined as biomass + net electricity to methanol for the biorefineries with electrolysis and as biomass to methanol + net electricity for the biorefineries without electrolysis. 
Table 1

Main process design parameters used in the modeling.

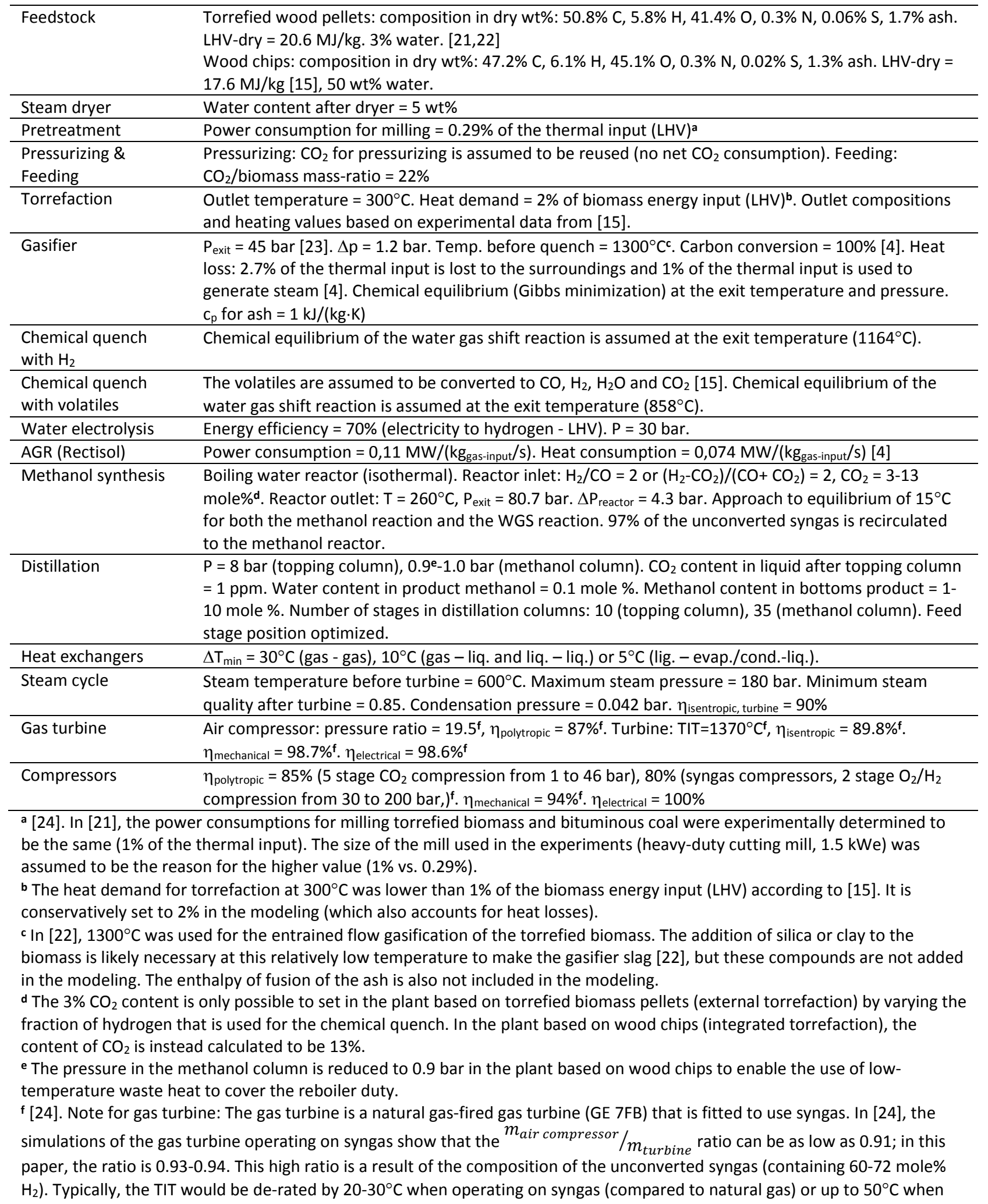


operating on hydrogen. However (as suggested in [24]), the historic increase in TIT is assumed to continue. Therefore, the TIT of $1370^{\circ} \mathrm{C}$ has not been de-rated. 
Table 2

Stream compositions for the methanol plant shown in Fig. 4 (integrated torrefaction).

\begin{tabular}{|c|c|c|c|c|c|c|c|c|c|}
\hline & $\begin{array}{r}\text { Gasifier } \\
\text { (before } \\
\text { quench) }\end{array}$ & $\begin{array}{r}\text { Gasifier } \\
\text { exit }\end{array}$ & $\begin{array}{r}\text { AGR } \\
\text { outlet }\end{array}$ & $\begin{array}{l}\text { Comp. } \\
\text { outlet }\end{array}$ & $\begin{array}{r}\text { Reactor } \\
\text { inlet }\end{array}$ & $\begin{array}{r}\text { Reactor } \\
\text { outlet }\end{array}$ & $\begin{array}{r}\text { Purge } \\
\text { gas }\end{array}$ & $\begin{array}{r}\text { To distil- } \\
\text { lation }\end{array}$ & $\begin{array}{r}\text { Recycle } \\
\mathrm{CO}_{2}\end{array}$ \\
\hline $\begin{array}{l}\text { Stream } \\
\text { number }\end{array}$ & - & 15 & 20 & 21 & 22 & 23 & 29 & $32^{a}$ & 34 \\
\hline $\begin{array}{l}\text { Mass flow } \\
(\mathrm{kg} / \mathrm{s})\end{array}$ & 33.3 & 44.2 & 40.0 & 43.4 & 110.8 & 110.8 & 2.1 & 41.4 & 4.3 \\
\hline $\begin{array}{l}\text { Mole flow } \\
(\mathrm{kmole} / \mathrm{s})\end{array}$ & 1.50 & 2.15 & 1.92 & 3.64 & 9.30 & 7.16 & 0.17 & 1.33 & 0.10 \\
\hline \multicolumn{10}{|c|}{ Mole frac (\%) } \\
\hline $\mathrm{H}_{2}$ & 23.8 & 32.5 & 36.7 & 66.6 & 70.0 & 58.8 & 72.1 & 0.27 & 3.6 \\
\hline $\mathrm{CO}$ & 55.8 & 43.0 & 48.3 & 25.4 & 15.2 & 7.2 & 8.8 & 0.06 & 0.75 \\
\hline $\mathrm{CO}_{2}$ & 9.1 & 13.2 & 14.7 & 7.7 & 13.1 & 14.8 & 16.5 & 7.1 & 92.5 \\
\hline $\mathrm{H}_{2} \mathrm{O}$ & 11.2 & 11.2 & - & - & 0.02 & 2.2 & 0.03 & 11.9 & 0.02 \\
\hline $\mathrm{CH}_{4}$ & 0.02 & 0.02 & 0.02 & 0.01 & 0.13 & 0.17 & 0.21 & 0.01 & 0.10 \\
\hline $\mathrm{H}_{2} \mathrm{~S}$ & 0.01 & 0.01 & - & - & - & - & - & - & - \\
\hline $\mathrm{N}_{2}$ & 0.20 & 0.14 & 0.16 & 0.08 & 1.1 & 1.4 & 1.7 & 0.01 & 0.14 \\
\hline $\mathrm{CH}_{3} \mathrm{OH}$ & - & - & 0.15 & 0.08 & 0.39 & 15.4 & 0.59 & 80.6 & 2.9 \\
\hline
\end{tabular}

a Liquid 
Table 3

Stream compositions for the methanol plant shown in Fig. 5 (external torrefaction).

\begin{tabular}{|c|c|c|c|c|c|c|c|c|c|}
\hline & $\begin{array}{r}\text { Gasifier } \\
\text { (before } \\
\text { quench) }\end{array}$ & $\begin{array}{r}\text { Gasifier } \\
\text { exit }\end{array}$ & $\begin{array}{r}\text { AGR } \\
\text { outlet }\end{array}$ & $\begin{array}{l}\text { Comp. } \\
\text { outlet }\end{array}$ & $\begin{array}{r}\text { Reactor } \\
\text { inlet }\end{array}$ & $\begin{array}{r}\text { Reactor } \\
\text { outlet }\end{array}$ & $\begin{array}{r}\text { Purge } \\
\text { gas }\end{array}$ & $\begin{array}{r}\text { To distil- } \\
\text { lation }\end{array}$ & $\begin{array}{r}\text { Recycle } \\
\mathrm{CO}_{2}\end{array}$ \\
\hline $\begin{array}{l}\text { Stream } \\
\text { number }\end{array}$ & - & 13 & 19 & 20 & 21 & 22 & 29 & $32^{a}$ & 34 \\
\hline $\begin{array}{l}\text { Mass flow } \\
(\mathrm{kg} / \mathrm{s})\end{array}$ & 186.9 & 191.0 & 148.6 & 159.3 & 317.9 & 317.9 & 4.9 & 154.4 & 6.2 \\
\hline $\begin{array}{l}\text { Mole flow } \\
(\text { kmole/s) }\end{array}$ & 8.75 & 10.76 & 9.06 & 14.39 & 26.43 & 17.20 & 0.37 & 4.80 & 0.16 \\
\hline \multicolumn{10}{|c|}{ Mole frac (\%) } \\
\hline $\mathrm{H}_{2}$ & 26.1 & 38.5 & 45.9 & 65.9 & 63.2 & 43.4 & 60.0 & 0.29 & 8.6 \\
\hline $\mathrm{CO}$ & 51.9 & 43.6 & 52.0 & 32.7 & 31.6 & 21.9 & 30.3 & 0.26 & 7.8 \\
\hline $\mathrm{CO}_{2}$ & 8.9 & 5.8 & 1.9 & 1.2 & 3.0 & 4.4 & 5.1 & 2.7 & 79.1 \\
\hline $\mathrm{H}_{2} \mathrm{O}$ & 12.9 & 11.9 & - & - & 0.00 & 0.17 & 0.00 & 0.60 & 0.00 \\
\hline $\mathrm{CH}_{4}$ & 0.03 & 0.02 & 0.04 & 0.03 & 0.29 & 0.45 & 0.61 & 0.03 & 0.83 \\
\hline $\mathrm{H}_{2} \mathrm{~S}$ & 0.02 & 0.02 & - & - & - & - & - & - & - \\
\hline $\mathrm{N}_{2}$ & 0.14 & 0.11 & 0.15 & 0.09 & 1.5 & 2.3 & 3.2 & 0.03 & 0.83 \\
\hline $\mathrm{CH}_{3} \mathrm{OH}$ & - & - & 0.05 & 0.03 & 0.32 & 27.3 & 0.67 & 96.1 & 2.9 \\
\hline
\end{tabular}

a Liquid 
Table 4

Main results from the modeling and analysis of the two biorefineries.

\begin{tabular}{|c|c|c|c|c|}
\hline & \multicolumn{2}{|c|}{ Integrated torrefaction } & \multicolumn{2}{|c|}{ External torrefaction } \\
\hline Biomass input [MWth ${ }_{\llcorner H V}$, dry] & & 500 & & 2906 \\
\hline Biomass input [dry kilotonne/day] & & 2.45 & & 14.24 \\
\hline Torrefied biomass input [MWth $\left.\mathrm{LHV}_{\mathrm{LH}, \mathrm{dry}}\right]$ & & - & & 2312 \\
\hline Torrefied biomass input [dry kilotonne/day] & & - & & 9.70 \\
\hline Methanol produced [MWth $\left.{ }_{\llcorner H V}\right]$ & & 681 & & 2940 \\
\hline Methanol produced [kilotonne/day] & & 2.95 & & 12.76 \\
\hline Methanol produced $\left[\mathrm{kg} / \mathrm{kg}_{\text {biomass, DAF }}\right]$ & & 1.22 & & - \\
\hline \multirow[t]{2}{*}{ Methanol produced $\left[\mathrm{kg} / \mathrm{kg}_{\text {torrefied iomass, DAF }}\right]$} & & - & \multirow{2}{*}{\multicolumn{2}{|c|}{ [\% of torrefied }} \\
\hline & \multicolumn{2}{|c|}{ [\% of biomass } & & \\
\hline Electricity consumption: & [MWe] & input] & [MWe] & biomass input] \\
\hline Electrolysis & 595 & 119 & 2536 & 110 \\
\hline Milling & 1 & $\sim 0$ & 7 & $\sim 0$ \\
\hline Compressors & 30 & 6 & 117 & 5 \\
\hline Acid gas removal (AGR) & 5 & 1 & 20 & 1 \\
\hline Total electricity consumption & 631 & 126 & 2680 & 116 \\
\hline \multicolumn{5}{|l|}{ Electricity production: } \\
\hline Steam cycle ${ }^{a}$ & 27 & 5 & 323 & 14 \\
\hline Gas turbine ${ }^{b}$ & 14 & 3 & 33 & 1 \\
\hline Total electricity production & 41 & 8 & 356 & 15 \\
\hline Net electricity consumption ${ }^{c}$ & 590 & 118 & 2324 & 101 \\
\hline \multicolumn{5}{|l|}{ Energy efficiencies and ratios (LHV) [\%]: } \\
\hline $\begin{array}{l}\text { Biomass to syngas } \\
\text { (Overall cold gas efficiency) }\end{array}$ & & 86 & & 63 \\
\hline Torrefied biomass to syngas & & - & & 80 \\
\hline Syngas (incl. $\mathrm{H}_{2}$ ) to methanol & & 80 & & 81 \\
\hline Biomass + net electricity to methanol (total efficiency) & & 62 & & 56 \\
\hline Biomass to methanol & & 136 & & 101 \\
\hline $\mathrm{H}_{2}$ to methanol & & 164 & & 166 \\
\hline Net electricity to methanol & & 115 & & 127 \\
\hline Torrefied biomass to methanol & & - & & 127 \\
\hline Torrefied biomass + net electricity to methanol & & - & & 63 \\
\hline \multicolumn{5}{|c|}{$\begin{array}{l}\text { a The thermal efficiency of the simple steam cycles ranges from } 36 \%\left(600^{\circ} \mathrm{C} \text { and } 43 \mathrm{bar}\right) \text { to } 39 \%\left(600^{\circ} \mathrm{C} \text { and } 136 \text { bar) }- \text { steam }\right. \\
\text { extraction is not included in these values. }{ }^{b} \text { The thermal efficiency of the gas turbine is } 37.9 \% .^{c} \text { This is the average electricity } \\
\text { consumption (when the electrolysis is operating, the consumption will be larger than this figure, but when the electrolysis is not } \\
\text { operating, the on-site power production will be greater than the on-site power consumption, resulting in net electricity } \\
\text { production) }\end{array}$} \\
\hline
\end{tabular}


Table 5

The main prerequisites for choosing one of the four different biorefineries

\begin{tabular}{|c|c|c|}
\hline & Electrolysis & No electrolysis \\
\hline $\begin{array}{l}\text { Integrated } \\
\text { torrefaction }\end{array}$ & $\begin{array}{l}\text { The cost of electricity is frequently lower than the } \\
\text { cost of biomass }{ }^{a}\end{array}$ & $\begin{array}{l}\text { The cost of electricity is always/almost always } \\
\text { higher than the cost of biomass }\end{array}$ \\
\hline $\begin{array}{l}\text { External } \\
\text { torrefaction }\end{array}$ & $\begin{array}{l}\text { The cost of electricity is frequently lower than the } \\
\text { cost of biomass }{ }^{a} \\
\text { and } \\
\text { Integrated torrefaction is too complex/expensive }{ }^{b} \\
\text { or does not work }^{c}\end{array}$ & $\begin{array}{l}\text { The cost of electricity is always/almost always } \\
\text { higher than the cost of biomass } \\
\text { and } \\
\text { Integrated torrefaction is too complex/expensive } \\
\text { or does not work }^{\mathrm{b}}\end{array}$ \\
\hline \multicolumn{3}{|c|}{$\begin{array}{l}\text { a per energy unit. For reference: The wood pellet price (PIX Pellet Nordic Index) has varied between } 28 \text { and } 31 € / M W h \text { in the } \\
\text { period 2010-2014 (wood chips is a more local product and typically cheaper) [25], and the average annual electricity price } \\
\text { (Nordpool system spot price) has varied between } 28 \text { and } 53 € / M W h \text { in the period } 2007-2013 \text { [26]. " "Complex" refers to the } \\
\text { need for pressurized torrefaction and/or pressurization of hot volatiles from torrefaction. "Expensive" refers to } 1 \text {. more } \\
\text { difficult/expensive transport, storage and handling of the biomass feedstock (wood chips); } 2 \text {. smaller plant size (economy of } \\
\text { scale); or 3. a larger methanol reactor (as shown in Table 6). c It needs to be confirmed through experiments that the volatiles } \\
\text { from torrefaction are converted completely to } \mathrm{CO}, \mathrm{H}_{2}, \mathrm{CO}_{2} \text { and } \mathrm{H}_{2} \mathrm{O} \text { in the quench. }\end{array}$} \\
\hline
\end{tabular}


Table 6

Fraction of carbon in the syngas as $\mathrm{CO}$ and the related impacts.

\begin{tabular}{|c|c|c|c|}
\hline & External torrefaction & Integrated torrefaction & $\begin{array}{l}\text { Integrated torrefaction } \\
\text { with } \mathrm{H}_{2} \text { quench }\end{array}$ \\
\hline \multicolumn{4}{|l|}{$\mathrm{CO} /(\mathrm{CO}+\mathrm{CO} 2)$, mole $\%$} \\
\hline Gasifier - before quench & 85 & 86 & 86 \\
\hline Gasifier - after quench with volatiles & - & 77 & 77 \\
\hline Gasifier - after $\mathrm{H}_{2}$ quench & $88^{b}$ & - & $85^{\circ}$ \\
\hline After AGR & 96 & 77 & 87 \\
\hline To methanol reactor & 91 & 54 & 69 \\
\hline Volume capacity of methanol reactord [\%] & 100 & 152 & 125 \\
\hline Purge gas chemical energy ${ }^{d}[\%$, LHV] & 100 & 175 & 134 \\
\hline Reboiler duty of methanol columnd,e [\%] & 100 & 123 & 118 \\
\hline
\end{tabular}

a If the electrolytic hydrogen was added to the syngas just after the quench with the volatiles instead of before the syngas compressor, it is assumed that the reverse water gas shift reaction (RWGS) reaches equilibrium after the addition of hydrogen, although the temperature is only $788^{\circ} \mathrm{C}$; a bed with active carbon could be used to promote the RWGS reaction. ${ }^{\mathrm{b}} 20 \%$ of the $\mathrm{CO}_{2}$ is converted to $\mathrm{CO}$ in the quench. ${ }^{\mathrm{c}} 38 \%$ of the $\mathrm{CO}_{2}$ is converted to $\mathrm{CO}$ in the quench. ${ }^{\mathrm{d}}$ per unit methanol produced. Normalized. ${ }^{e}$ The preheating before the methanol column is here considered a part of the reboiler duty. 